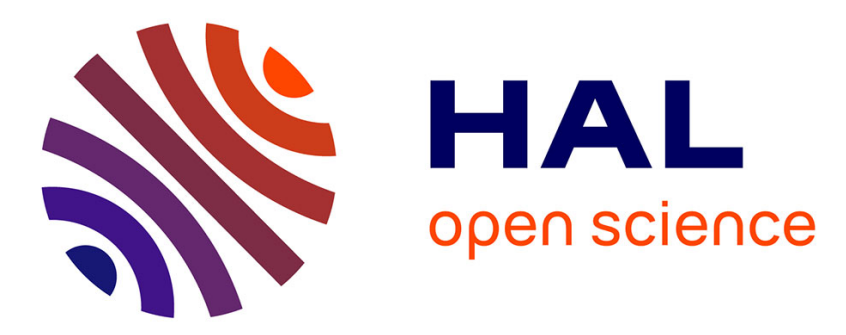

\title{
Ventilatory responses during experimental cycle-run transition in triathletes
}

Olivier Hue, Daniel Le Gallais, Alain Boussana, Didier Chollet, Christian

Prefaut

\section{- To cite this version:}

Olivier Hue, Daniel Le Gallais, Alain Boussana, Didier Chollet, Christian Prefaut. Ventilatory responses during experimental cycle-run transition in triathletes. Medicine and Science in Sports and Exercise, 1999, pp.1422-1428. 10.1097/00005768-199910000-00010 . hal-00720412

\section{HAL Id: hal-00720412 https://hal.univ-antilles.fr/hal-00720412}

Submitted on 24 Jul 2012

HAL is a multi-disciplinary open access archive for the deposit and dissemination of scientific research documents, whether they are published or not. The documents may come from teaching and research institutions in France or abroad, or from public or private research centers.
L'archive ouverte pluridisciplinaire $\mathbf{H A L}$, est destinée au dépôt et à la diffusion de documents scientifiques de niveau recherche, publiés ou non, émanant des établissements d'enseignement et de recherche français ou étrangers, des laboratoires publics ou privés. 


\title{
Ventilatory responses during experimental cycle-run transition in triathletes
}

\author{
OLIVIER HUE, DANIEL LE GALLAIS, ALAIN BOUSSANA, DIDIER CHOLLET, and CHRISTIAN PREFAUT
}

Centre d'Optimisation de la Performance Motrice, Laboratoire Sport, Santé, Développement, UFR-STAPS, 34090 Montpellier, FRANCE; and Laboratoire de Physiologie des Interactions, Service Central de Physiologie Clinique, Unité

Cedex 5, FRANCE
Cedion Respiratoire, Centre Hospitalier Universitaire Arnaud de Villeneuve, 34295 MONTPELLIER

\begin{abstract}
HUE, O., D. LE GALLAIS, A. BOUSSANA, D. CHOLLET, and C. PREFAUT. Ventilatory responses during experimental cycie-run transition in triathletes. Med. Sci. Sports Exerc., Vol. 31, No. 10, pp. 1422-1428, 1999. Purpose and Methods: To determine the effects of cycling on a subsequent triathlon run, nine male triathletes underwent four successive laboratory trials: 1) an incremental treadmill test, 2) an incremental cycle test, 3) $30 \mathrm{~min}$ of cycling followed by $5 \mathrm{~km}$ of running (C-R), and 4) 30 min of running followed by 5 $\mathrm{km}$ of running (R-R). Before and $10 \mathrm{~min}$ after the third and fourth trials, the triathletes underwent pulmonary function testing including spirometry and diffusing capacity testing for carbon monoxide $\left(\mathrm{DL}_{\mathrm{Co}}\right)$. During the $\mathrm{C}-\mathrm{R}$ and $\mathrm{R}-\mathrm{R}$ trials, arterialized blood samples were obtained to measure arterial oxygen pressure $\left(\mathrm{PaO}_{2}\right)$. During all trials, ventilatory data were collected every minute using an automated breath-by-breath system. Results: The results showed that 1$)$ the oxygen uptake $\left(\mathrm{VO}_{2}\right)$ observed during subsequent running was similar for the $C-R$ and $R-R$ trials; 2$)$ the ventilatory response $\left(\dot{V}_{E}\right)$ during the first 8 min of subsequent running was significantly greater in the C-R than in R-R trial $(P<0.05) ; 3)$ only the $C-\mathrm{R}$ trial induced a significant increase $(P<0.05)$ in residual volume (RV), functional residual capacity (FRC), and the ratio of residual volume to total lung capacity (RV/TLC); and 4) although a significant decrease $(P<$ 0.05 ) in $\mathrm{DL}_{\mathrm{CO}}$ was noted after $\mathrm{C}-\mathrm{R}$, no difference between the two exercise trials was found for the maximal drop in $\mathrm{PaO}_{2}$. Conclusions: We concluded that $\mathrm{I}$ ) the $\mathrm{C}-\mathrm{R}$ trial induced specific alterations in pulmonary function that may be associated with respiratory muscle fatigue and/or exercise-induced hypoxemia. and 2) the greater $\dot{V}_{E}$ observed during the first minute of running after cycling was due to the specificity of cycling. This reinforces the necessity for triathletes to practice multi-trial training to stimulate the physiological EXERCISE-INDUCED HYPOXEMIA, RESPIRATORY EXERCISE-INDUCED HYPOXEMIA, RESPIRATORY MUSCLE FATIGUE, MULTI-TRIAL TRAINING
\end{abstract}

$\mathrm{T}$ The higher oxygen uptake $\left(\mathrm{VO}_{2}\right)$ observed during the triathlon run $(\mathrm{CR})$ compared with the run alone $(\mathrm{R})$ has been widely reported in the literature $(14,15,22,23)$. Possible causes for the greater $\mathrm{VO}_{2}$ may include biomechanical factors such as changes in stride length and stride frequency, trunk tilting, the center of gravity position and its kinetics, and knee elevation $(13,15,28,41)$. Physiological factors, such as changes in thermoregulation and dehydration (14), carbohydrate replacement by fat oxidation (6), and the lipid mobilization that has been reported to occur at the end of a triathlon (43) concomitant with the muscle glycogen depletion induced by the preceding cycling bout (18), have also been suggested to explain the $\mathrm{VO}_{2}$ rise.

Recently, our group (18) confirmed in the laboratory that cycling induces a higher $\mathrm{VO}_{2}$ in CR compared with $\mathrm{R}$. Furthermore, we demonstrated that cycling increased the

$0195-9131 / 99 / 3110-1422 / 0$

MEDICINE \& SCIENCE IN SPORTS \& EXERCISE

Copyright $\odot 1999$ by the American College of Sports Medicine

Submitted for publication April 1998.

Accepted for publication January 1999. ventilatory response $\left(\dot{\mathrm{V}}_{\mathrm{E}}\right)$, breathing frequency (f), and respiratory equivalents for $\mathrm{O}_{2}\left(\dot{\mathrm{V}}_{\mathrm{E}} / \dot{\mathrm{VO}}_{2}\right)$ and $\mathrm{CO}_{2}\left(\dot{\mathrm{V}}_{\mathrm{E}} / \dot{\mathrm{V} C O_{2}}\right)$ during subsequent running. These respiratory alterations were most accentuated during the first minute of running after cycling, a period that was termed the "cycle-run transition" (CR-T). These findings suggest respiratory muscle fatigue and/or pulmonary interstitial edema as possible causes. Indeed, such an increase in both $\dot{\mathrm{V}}_{\mathrm{E}} / \dot{\mathrm{VO}}_{2}$ and $\dot{\mathrm{V}}_{\mathrm{E}} /$ $\mathrm{VCO}_{2}$, associated with an increase in $\mathrm{f}$, has been reported to occur during respiratory muscle fatigue in normal subjects (25), triathletes (16), and marathon runners (11). Increased ventilation has also been reported during pulmonary interstitial edema $(3,19)$. Moreover, respiratory muscle fatigue and pulmonary interstitial edema may be associated with exercise-induced hypoxemia (EIH) in triathletes (7) and in older athletes (35).

The present study was designed to determine whether a cycle-run trial ( $C-R)$ would produce changes in pulmonary function that are not observed during a run-run trial (R-R). We measured lung volumes, diffusion capacity for carbon monoxide, EIH, and exercise ventilation between two balanced experimental trials: C-R and R-R. We were specifically interested in whether ventilatory responses during the first minute of running after cycling (the transition phase: 
TABLE 1. General physical characteristics, training regimen data and results of the La Grande-Motte Triathlon (1.5-km swim, 40-km cycle, 10-km run) for nine male triathietes: Training distances were averaged during the period of the study.

\begin{tabular}{|c|c|c|c|c|c|c|c|c|}
\hline \multirow[b]{2}{*}{$\begin{array}{c}\text { Subject } \\
\text { No. }\end{array}$} & \multirow[b]{2}{*}{$\begin{array}{l}\text { Age } \\
\text { (yr) }\end{array}$} & \multirow[b]{2}{*}{$\begin{array}{l}\text { Height } \\
\text { (cm) }\end{array}$} & \multirow[b]{2}{*}{$\begin{array}{l}\text { Weight } \\
\text { (kg) }\end{array}$} & \multicolumn{3}{|c|}{ Mean Training Distances (km+wk-1) } & \multicolumn{2}{|c|}{$\begin{array}{l}\text { La Grande-Motte } \\
\text { Triathlon }\end{array}$} \\
\hline & & & & Swim & Bike & Run & $\begin{array}{c}\text { Time } \\
\text { (h:min) }\end{array}$ & Place \\
\hline $\begin{array}{l}1 \\
2 \\
3 \\
4 \\
5 \\
6 \\
7 \\
8 \\
9\end{array}$ & $\begin{array}{l}23 \\
21 \\
25 \\
21 \\
20 \\
18 \\
18 \\
20 \\
22\end{array}$ & $\begin{array}{l}193 \\
184 \\
181 \\
167 \\
180 \\
180 \\
190 \\
165 \\
168\end{array}$ & $\begin{array}{l}83 \\
77 \\
69 \\
56 \\
65 \\
75 \\
80 \\
59 \\
64\end{array}$ & $\begin{array}{c}18 \\
18 \\
12 \\
15 \\
18 \\
18 \\
7.5 \\
3 \\
21\end{array}$ & $\begin{array}{l}350 \\
270 \\
300 \\
250 \\
200 \\
120 \\
200 \\
450 \\
300\end{array}$ & $\begin{array}{l}60 \\
45 \\
55 \\
75 \\
45 \\
30 \\
40 \\
25 \\
35\end{array}$ & $\begin{array}{l}1: 44 \\
1: 45 \\
1: 46 \\
1: 54 \\
1: 55 \\
1: 56 \\
1: 57 \\
2: 04 \\
2: 11\end{array}$ & $\begin{array}{r}6 \\
11 \\
17 \\
56 \\
60 \\
65 \\
80 \\
171 \\
236\end{array}$ \\
\hline $\begin{array}{l}\text { Mean } \\
\text { SD }\end{array}$ & $\begin{array}{r}20.9 \\
2.3\end{array}$ & $\begin{array}{r}178.7 \\
10.1\end{array}$ & $\begin{array}{r}69.8 \\
9.5\end{array}$ & $\begin{array}{r}14.8 \\
5.9\end{array}$ & $\begin{array}{r}267.5 \\
95.7\end{array}$ & $\begin{array}{l}44.4 \\
15.7\end{array}$ & $\begin{array}{l}1: 54 \\
0: 09\end{array}$ & \\
\hline
\end{tabular}

CR-T) would be augmented compared with the responses in the first minute of running after running.

\section{METHODS AND PROCEDURES}

Subjects. Nine male competitive triathletes participated this study. All subjects gave written consent to participate atter the design and risks of the study had been described to them. The study protocol was in accordance with legal requirements and the Declaration of Helsinki, and it was approved by the regional ethics committee. Subjects were students at the School of Physical Education at the University of Montpellier, France, and members of the university iletic team. This team has been French national university ti: athlon champion for four consecutive years. Subjects had been competing in triathlons for $5.0 \mathrm{yr}( \pm 2.3 \mathrm{yr})$ and were in the competitive period at the time of the study. General physical characteristics and the training regimen data are presented in Table 1.

Testing protocol. Each subject was tested in a fourtrial protocol that took place over four consecutive weeks. . e tests were conducted at the same time of day and during the same day of the week to minimize the effects of personal training on the results. The subjects were asked to maintain their training schedule for the duration of the study but were not allowed to compete in a triathlon during the testing period. All subjects were familiarized with treadmill running and with the use of the cycle ergometer before testing. $T$. e subjects were asked to refrain from training on experimental days. Trial 1 consisted of an incremental treadmill test; trial 2, an incremental cycle test; trial 3, $30 \mathrm{~min}$ of cycling followed by $5 \mathrm{~km}$ of running (C-R); and trial 4, 30 min of running at the same metabolic cost as the $30 \mathrm{~min}$ of cycling followed by $5 \mathrm{~km}$ of running (R-R) at the same speed as $\mathrm{C}-\mathrm{R}$ running. The running and cycling $\mathrm{VO}_{2 \max }$ and ventilatory threshold $\left(\mathrm{Th}_{\mathrm{vent}}\right)$ values measured in trials 1 and 2 vere used to monitor the cycling and running intensities during the C-R and R-R trials. The incremental treadmill (Gymroll 1800, Gymroll, Roche La Molière, France) test began at $5 \mathrm{~km} \cdot \mathrm{h}^{-1}$ for $1 \mathrm{~min}$ at $0 \%$ grade. The speed was then increased by $1 \mathrm{~km} \cdot \mathrm{h}^{-1}$ every minute up to a maximum speed of $18 \mathrm{~km} \cdot \mathrm{h}^{-1}$. The speed was then held constant and

VENTILATORY RESPONSES IN TRIATHLETES the grade was increased by $1 \%$ every minute until the subject reached exhaustion. The incremental cycle test was performed on an electromagnetic cycle ergometer (Monark 864, Monark-Crescent AB, Varburg, Sweden). After a 3-min warm-up at $30 \mathrm{~W}$, the power was then increased by $30 \mathrm{~W}$ every minute until the subject reached volitional fatigue. In trial 3 , the cycling was performed by the triathletes using their own cycle set on a home trainer (Cycletrack, Tacx, Aardenburg, Holland). The speed and gear ratios were calculated to be close to the athlete's performance level in the triathlon and above the $\mathrm{Th}_{\text {vent }}$ calculated in trial 2. At the end of the $30 \mathrm{~min}$ of cycling, the subjects had 1 min to change their shoes and get on the treadmill. This time corresponded approximately to the cycle-run change time in an official triathlon. The athletes began the $5-\mathrm{km}$ run at a speed calculated to be close to their performance level in a classic triathlon and above the $\mathrm{Th}_{\text {vent }}$ calculated in trial 1 . This run speed was reached in less than $1 \mathrm{~min}$. The triathletes then adjusted their run speed by 0.5 $\mathrm{km} \cdot \mathrm{h}^{-1}$ each minute to optimize their running time performance. In trial 4, triathletes $\operatorname{ran} 30 \mathrm{~min}$ at the same $\mathrm{VO}_{2}$ as during the $30 \mathrm{~min}$ of cycling in trial 3 by adjustment of the running speed by $0.5 \mathrm{~km} \cdot \mathrm{h}^{-1} \cdot \mathrm{min}^{-1}$; they then had 1 min of rest that corresponded to the time to change shoes in trial 3, and then ran $5 \mathrm{~km}$ at exactly the same running speed variations used during the $5-\mathrm{km}$ run in trial 3 .

Gas exchange measurements. Metabolic and cardiopulmonary data were measured every minute using a mass spectrometer breath-by-breath automated system (MGA-1100, Marquette, NY): minute ventilation $\left(\dot{\mathrm{V}}_{\mathrm{E}}\right)$, oxygen uptake $\left(\dot{\mathrm{VO}}_{2}\right)$, carbon dioxide production $\left(\dot{\mathrm{VCO}}_{2}\right)$, respiratory equivalents for $\mathrm{O}_{2}\left(\dot{\mathrm{V}}_{\mathrm{E}} / \mathrm{VO}_{2}\right)$ and $\mathrm{CO}_{2}\left(\dot{\mathrm{V}}_{\mathrm{E}} /\right.$ $\mathrm{VCO}_{2}$ ), respiratory exchange ratio (RER), breathing frequency ( $\mathrm{f}$ ), and tidal volume $\left(\mathrm{V}_{\mathrm{T}}\right)$. Heart rate (HR) was measured using a telemetry system (Polar Racer, Polar Electro, Kempele, Finland). The $\mathrm{Th}_{\text {vent }}$ was automatically determined using the V-slope method of Beaver et al. (4). This method involves the analysis of $\mathrm{VCO}_{2}$ plotted as a function of $\mathrm{VO}_{2}$ and assumes that the $\mathrm{Th}_{\text {vent }}$ corresponds to the breakpoint in the $\mathrm{VCO}_{2}-\mathrm{VO}_{2}$ relationship.

$\mathrm{O}_{2}$ partial pressure. Blood samples were obtained from the ear lobe at rest, at 15, 30, and $40 \mathrm{~min}$ of exercise, 

TABLE 2. Maximal oxygen uptake ( $\mathrm{VO}_{2}$ max), ventilatory threshold $\left(\mathrm{Th}_{\text {vent }}\right)$, and heart rate $(\mathrm{HR})$ values obtained during incremental cycling and during treadmill running; no
significant differences between cycling and treadmill running were observed; values presented are means $\pm \mathrm{SD}$.

\begin{tabular}{|c|c|c|c|c|c|c|}
\hline \multirow{3}{*}{$\begin{array}{l}\text { Mode of } \\
\text { Exercise }\end{array}$} & \multicolumn{3}{|c|}{$\dot{\mathrm{v}}_{2}$} & \multicolumn{3}{|c|}{ HR } \\
\hline & \multirow{2}{*}{$\frac{\max }{\mathrm{mL} \cdot \mathrm{kg} \cdot \mathrm{min}^{-1}}$} & \multicolumn{2}{|c|}{$\mathrm{Th}_{\text {vent }}$} & \multirow{2}{*}{$\frac{\max }{\text { beats } \cdot \min ^{-1}}$} & \multicolumn{2}{|c|}{$T h_{\text {vent }}$} \\
\hline & & $\mathrm{mL} \cdot \mathrm{kg} \cdot \min ^{-1}$ & $\% \dot{V}_{2}$ max & & beats.min ${ }^{-1}$ & $\% H R_{\max }$ \\
\hline $\begin{array}{l}\text { Cycle ergometer } \\
\text { Treadmill }\end{array}$ & $\begin{array}{l}70.0 \pm 3.8 \\
71.7 \pm 4.9 \\
\end{array}$ & $\begin{array}{l}47.1 \pm 7.3 \\
45.3 \pm 3.7 \\
\end{array}$ & $\begin{array}{l}67.0 \pm 8.0 \\
63.3 \pm 6.0\end{array}$ & $\begin{array}{l}181 \pm 9 \\
189 \pm 6 \\
\end{array}$ & $\begin{array}{l}144 \pm 11 \\
152 \pm 8 \\
\end{array}$ & $\begin{array}{l}79.6 \pm 4.6 \\
80.5 \pm 4.0\end{array}$ \\
\hline
\end{tabular}

and at the end of exercise. These samples were immediately analyzed for $\mathrm{PaO}_{2}$, arterial pressure of $\mathrm{CO}_{2}\left(\mathrm{PaCO}_{2}\right)$, and $\mathrm{pH}$ at $37^{\circ} \mathrm{C}$ using the appropriate electrode (IL Meter 1306 , Milan, Italy). The instrument was calibrated before each test using the same gas mixture as for the expired gas analyzers. Subjects were considered to have developed EIH if $\mathrm{PaO}_{2}$ decreased by at least $8 \mathrm{~mm} \mathrm{Hg} \mathrm{(35)}$.

Pulmonary volumes. Spirometric measurements were obtained (Pulmonet III, SensorMedics, Anaheim, CA) 10 min before and $10 \mathrm{~min}$ after $\mathrm{C}-\mathrm{R}$ and $\mathrm{R}-\mathrm{R}$. Total lung capacity (TLC), vital capacity (VC), residual volume (RV), functional residual capacity (FRC), and the ratio of residual volume to total lung capacity (RV/TLC) were determined. Residual volume and FRC were measured using the multibreath helium equilibrium method (Pulmonet III, SensorMedics, Anaheim, CA) according to recommended procedures (36). About $7 \mathrm{~min}$ were allowed for intrapulmonary equilibrium of the mixture of helium, oxygen, and air. After this. several slow inspiratory capacity maneuvers were performed to enhance equilibrium.

Pulmonary diffusing capacity. Pulmonary diffusing capacity for carbon monoxide $\left(\mathrm{DL}_{\mathrm{CO}}\right.$ ) was measured during breath-holding while seated using an automated transfer apparatus (Transfer Test, Morgan. Chatham, Kent, UK). After a full exhalation, subjects inhaled a gas mixture $(10 \%$ $\mathrm{He}, 21 \% \mathrm{O}_{2}$, and $2.800 \mathrm{ppm} \mathrm{CO}$, in $\mathrm{N}_{2}$ ), held their breath for $9 \mathrm{~s}$, and finally executed a rapid exhalation (1).

Statistical analysis. The results are expressed as means $\pm S D$. After verification of a normal distribution (Gaussian graphical distribution), metabolic and cardiopulmonary data such as $\dot{\mathrm{VO}} \mathrm{O}_{2}, \dot{\mathrm{V}}_{\mathrm{E}}, \dot{\mathrm{V}}_{\mathrm{E}} / \dot{\mathrm{VO}}_{2}, \dot{\mathrm{V}}_{\mathrm{E}} / \dot{\mathrm{VCO}}_{2}, \mathrm{R}, \mathrm{V}_{\mathrm{T}}$, f, and $\mathrm{HR}$ were compared using a two-way ANOVA with repeated measures for $C-R$ versus $R-R$. When significant results were obtained, post hoc comparisons were made using the contrast method (46). The maximal drop in $\mathrm{PaO}_{2}$ data were compared using a Student's paired $t$-test. The relationship between the increase in $\dot{\mathrm{V}}_{\mathrm{E}}$ and the drop in $\mathrm{PaO}_{2}$ was calculated using the least-squares method. Lung volume and $\mathrm{DL}_{\mathrm{CO}}$ values were compared before and after trials 3 and 4 (C-R and R-R, respectively) to analyze the influence of specific exercise on pulmonary function using a one-way ANOVA. Statistical significance was accepted at the $P<$ 0.05 level.

\section{RESULTS}

Incremental tests. Maximal oxygen uptake and $\mathrm{Th}_{\mathrm{vent}}$ values obtained for cycling and running in triathletes in the present study (Table 2) were in agreement with values previously reported $(31,38,39)$.

Exercise intensity. The $30 \mathrm{~min}$ of cycling and $30 \mathrm{~min}$ of running were performed at $68.7 \%$ and $67.1 \% \mathrm{VO}_{2 \max }$. respectively, and the subsequent $C-R$ and $R-R 5-k m$ runs were performed at $69.3 \% \mathrm{VO}_{2 \max }$. These intensities were at $\mathrm{Th}_{\text {vent }}\left(67.0 \%\right.$ and $63.3 \% \mathrm{VO}_{2 \max }$ for cycling and running. respectively). which indicates that the experimental $C-R$ and $\mathrm{R}-\mathrm{R}$ trials were performed at a relatively high intensity.

\section{C-R versus $R-R$ Trials}

30-min cycling versus $30-\mathrm{min}$ running. As expected from this experimental design, the oxygen uptake and cardiopulmonary responses for 30 min of cycling versus running showed no significant differences and suggested that the triathletes had similar energy expenditure during 30 min of cycling and 30 min of running (Table 3 ).

Subsequent 5-km run. There were no significant differences in mean $\mathrm{VO}_{2}$ and cardiopulmonary responses in the subsequent 5 -km run of $\mathrm{C}-\mathrm{R}$ compared with $\mathrm{R}-\mathrm{R}$, except in mean $\dot{\mathrm{V}}_{\mathrm{E}} / \mathrm{VO}_{2}$, which was significantly higher $(P<0.05)$ in the $\mathrm{C}-\mathrm{R}$ run (Table 3 ).

However, when we compared these values for the first 10 min of the two trials, we found that the mean $\dot{V}_{E}$, f, and $\dot{\mathrm{V}}_{\mathrm{E}} / \dot{\mathrm{VO}}_{2}$ values were significantly higher for $\mathrm{C}-\mathrm{R}$ than for $\mathrm{R}-\mathrm{R},(P<0.05): \dot{\mathrm{V}}_{\mathrm{E}}\left(91.1 \pm 19.5\right.$ vs $\left.82.9 \pm 15.5 \mathrm{~L} \cdot \mathrm{min}^{-1}\right)$. f $\left(48.3 \pm 8.9\right.$ vs $46.2 \pm 7.4$ breaths $\left.\cdot \mathrm{min}^{-1}\right)$, and $\dot{\mathrm{V}}_{\mathrm{E}} / \mathrm{VO}_{2}$

TABLE 3. Metabolic and cardiopulmonary values measured during $30 \mathrm{~min}$ of cycling and running and the $5 \cdot \mathrm{km}$ run; values presented are means $\pm \mathrm{SD}$.

\begin{tabular}{|c|c|c|c|c|}
\hline \multirow[b]{2}{*}{ Variables } & \multicolumn{2}{|c|}{$30 \mathrm{~min}$} & \multicolumn{2}{|c|}{$5 \mathrm{~km}$} \\
\hline & Cycle & Run & After Cycle & After Run \\
\hline 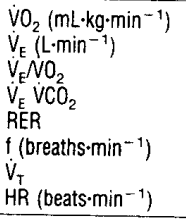 & $\begin{aligned} 48.1 & \pm 3.9 \\
88.7 & \pm 15.1 \\
22.2 & \pm 2.9 \\
22.7 & \pm 2.0 \\
0.97 & \pm 0.03 \\
40.4 & \pm 6.5 \\
2221 & \pm 387 \\
159 & \pm 11\end{aligned}$ & $\begin{aligned} 48.1 & \pm 4.2 \\
84.4 & \pm 9.8 \\
21.7 & \pm 1.9 \\
22.8 & \pm 2.0 \\
0.94 & \pm 0.03 \\
44.0 & \pm 6.5 \\
1975 & \pm 321 \dagger \\
159 & \pm 12\end{aligned}$ & $\begin{aligned} 49.7 & \pm 4.1 \\
96.3 & \pm 19.6 \\
23.7 & \pm 2.5^{*} \\
24.7 & \pm 2.0 \\
0.95 & \pm 0.03 \\
49.5 & \pm 8.5 \\
2002 & \pm 371 \\
169 & \pm 9\end{aligned}$ & $\begin{aligned} 49.7 & \pm 3.0 \\
89.8 & \pm 13.0 \\
22.1 & \pm 2.1 \\
23.5 & \pm 3.0 \\
0.94 & \pm 0.03 \\
47.8 & \pm 7.8 \\
1955 & \pm 353 \\
168 & \pm 10\end{aligned}$ \\
\hline
\end{tabular}

run after run.

$\dagger P<0.0530$-min run versus 30 -min cycle. 

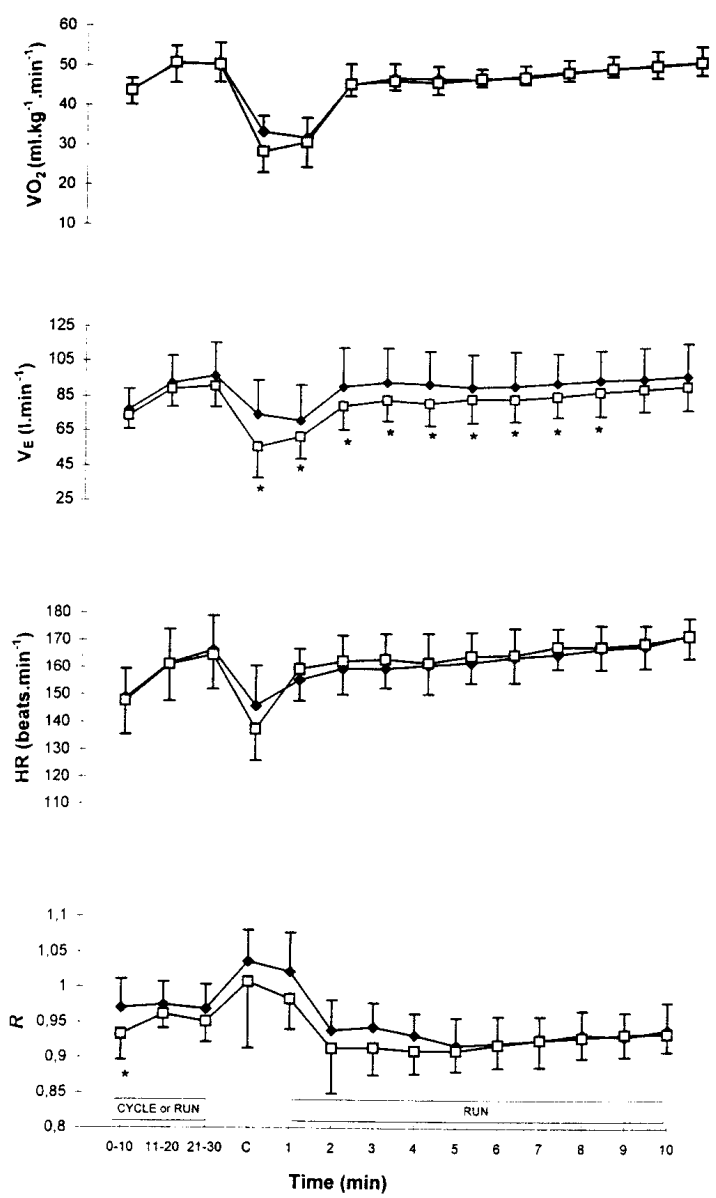

Figure 1-Metabolic and cardiopulmonary variables during the 30 min of cycling $(\bullet)$ and running $(\square)$, the cycle-run change $(C)$, and the first $10 \mathrm{~min}$ of subsequent running: running after cycling $(\downarrow)$ and "unning after running $(\square)$. * Ventilation during the first minute of ubsequent running was significantly higher after cycling than after cunning.

$(23.8 \pm 3.0$ vs $22.0 \pm 3.0)$. Moreover, when compared minute-by-minute, the $\dot{V}_{E}$ values obtained during the subsequent running transition were significantly higher $(P<$ $0.05)$ during the first 8 min of C-R compared with the first 8 min of R-R (Fig. 1).

Exercise-induced hypoxemia. During the C-R and $R-R$ trials, a significant drop in $\mathrm{PaO}_{2}$ was observed in all subjects, but neither the time course of average $\mathrm{PaO}_{2}$ (Fig. 2) nor the maximal drop in $\mathrm{PaO}_{2}$ was greater in $\mathrm{C}-\mathrm{R}$ versus $\mathrm{R}-\mathrm{R}(12.6 \pm 2.9 \mathrm{~mm} \mathrm{Hg}$ vs $14.4 \pm 2.1 \mathrm{~mm} \mathrm{Hg}$, respectively). However, a significant negative correlation $(\mathrm{r}=$ $-0.76, P=0.038$ ) was observed between the drop in $\mathrm{PaO}_{2}$ and the $\dot{V}_{E}$ increase (5-km running vs 30 -min cycling) in $\mathrm{C}-\mathrm{R}$ but not in $\mathrm{R}-\mathrm{R}$ (5-km running vs 30 -min running).

Pulmonary volumes. Residual volume $(1.51 \pm 0.23 \mathrm{~L}$ vs $1.63 \pm 0.23 \mathrm{~L}), \mathrm{FRC}(3.66 \pm 0.41 \mathrm{~L}$ vs $3.92 \pm 0.52 \mathrm{~L})$, and RV/TLC $(20.2 \pm 3.22 \%$ vs $21.5 \pm 3.03 \%)$ were all significantly higher $(P<0.05)$ after $\mathrm{C}-\mathrm{R}$ compared with VENTILATORY RESPONSES IN TRIATHLETES before C-R (Fig. 3). The R-R trial did not produce significant changes in these lung volumes.

Pulmonary diffusing capacity. $\mathrm{DL}_{\mathrm{CO}}$ was significantly reduced $(P<0.05)$ after the $\mathrm{C}-\mathrm{R}$ trial $(39.69 \pm 5.61$ vs $43.01 \pm 7.07 \mathrm{mmol} \cdot \mathrm{min}^{-1} \cdot \mathrm{mm} \mathrm{Hg}^{-1}$, respectively, after and before C-R) but not after the R-R trial (Fig. 3).

\section{DISCUSSION}

The present study showed that the energy cost of running is the same after $30 \mathrm{~min}$ of cycling and $30 \mathrm{~min}$ of running. However, a significantly higher ventilatory response was observed during running after cycling than during running after running. Moreover, the cycle-run trial induced significant increases in RV, FRC, and the FRC/TLC ratio. A significant reduction in $\mathrm{DL}_{\mathrm{CO}}$ when compared with a runrun trial matched for intensity and duration was observed but the level of EIH was the same for both trials.

Exercise specificity. The similar $\dot{\mathrm{VO}}_{2}$ of the two subsequent running segments agrees with the hypothesis that metabolic factors (i.e., fatigue), rather than biomechanical factors, are involved in the greater energy cost of running after cycling versus running alone reported in the literature $(14,18,22,43)$. Indeed, the principal cause for the higher $\mathrm{VO}_{2}$ observed in the triathlon run in previous studies was suggested to be changes in the optimal stride induced by the cycling segment (13), which could decrease the running economy $(10.17,28)$. However, these studies compared 10 $\mathrm{km}$ of running with $10 \mathrm{~km}$ of running subsequent to $40 \mathrm{~km}$ of cycling, and thus the involvement of physiological parameters (i.e., fatigue induced by prior exercise) and/or biomechanical parameters (i.e., alterations in the biomechanical pattern of running induced by the preceding cycle bout) could not be differentiated. For the first time, to our knowledge, this study compared the $\mathrm{VO}_{2}$ in two balanced run segments: one after $30 \mathrm{~min}$ of cycling and the other after $30 \mathrm{~min}$ of running matched in intensity to the cycling. The results showed no difference in the $\mathrm{VO}_{2}$ of subsequent running in $C-R$ compared with $R-R$, which strongly suggests that the increase in the energy cost of running after cycling

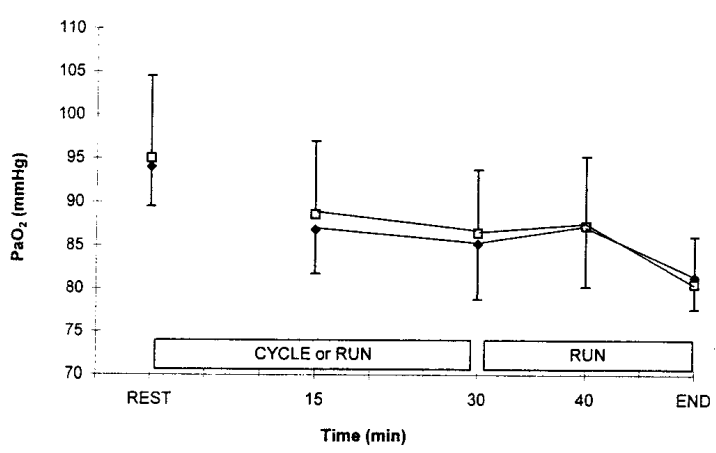

Figure 2-Average (mean $\pm \mathrm{SD}$ ) $\mathrm{PaO}_{2}$ values presented as a function of time in triathletes in cycle-run ( $)$ compared with run-run ( $\square$ ). There was a significant drop in arterialized oxygen pressure $\left(\mathrm{PaO}_{2}\right)$ during the two exercise modes, but the time course of averaged $\mathrm{PaO}_{2}$ was not significantly different. 

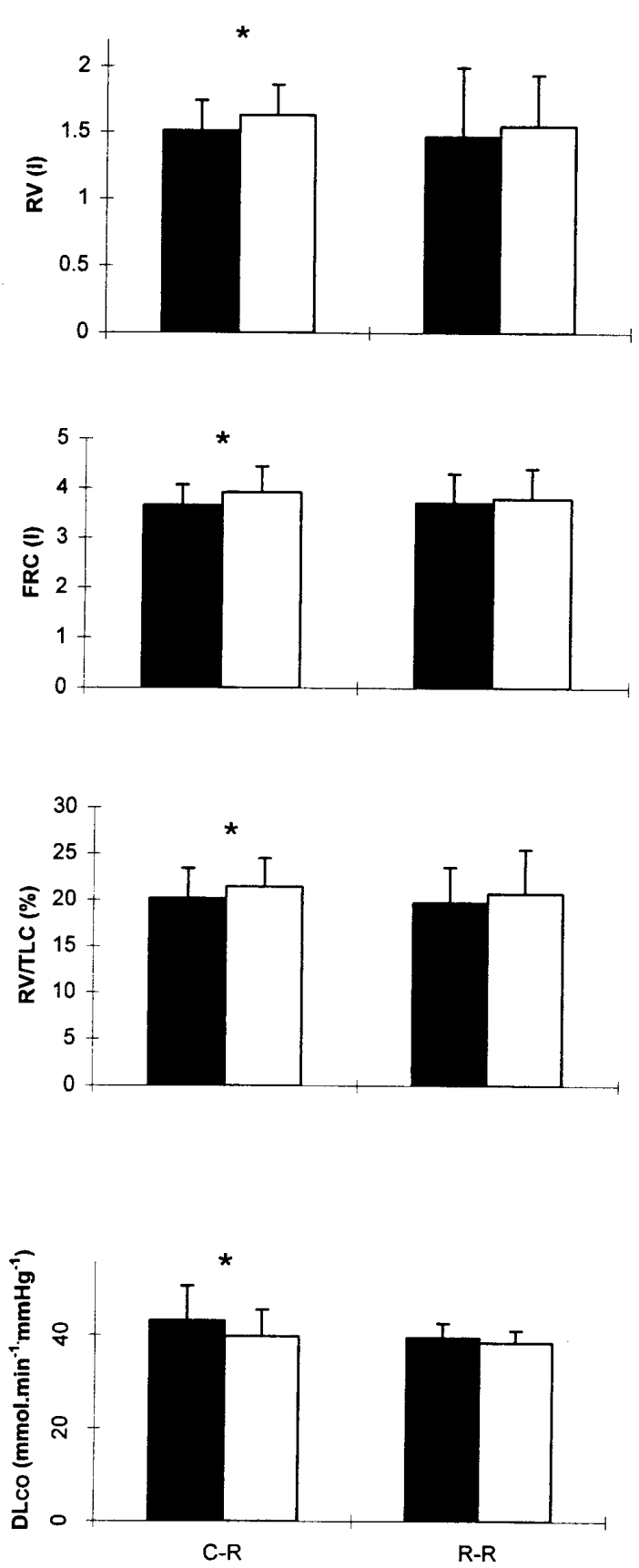

Figure 3-Mean values of residual volume (RV), functional residual capacity (FRC), the ratio of residual volume to total lung capacity (RV/TLC) and pulmonary diffusing capacity for carbon monoxide $\left(\mathrm{DL}_{\mathrm{Co}}\right)$ before $(\bullet)$ and after $(\square)$ cycle-run and run-run. *Significant differences before and after exercise.

versus running alone reported in the previous studies has to be attributed simply to the performance of a prior exercise.

Respiratory muscle alteration. The significant increase in FRC, RV, and RV/TLC in post-C-R versus pre-
$\mathrm{C}-\mathrm{R}$ suggests a respiratory system disturbance. This disturbance could be due to respiratory muscle fatigue induced by the cycling and may also be enhanced by an extravascular water accumulation. Indeed, the primary determinants of static lung volumes are the inspiratory and expiratory pressures generated by the respiratory muscles (29). A decrease in FRC and RV may indicate respiratory muscle fatigue, particularly expiratory muscle fatigue $(12,30)$, which has been hypothesized to be due to a marked decrease in the force of the respiratory muscle $(20,29,30)$. Although we did not measure respiratory muscle force, we cannot rule out the possibility that the crouched position of cycling, which increases diaphragmatic work by augmenting abdominal impedance (16), may have led to a greater respiratory muscle recruitment during the cycle-run trial. This would have led to a marked decrease in the respiratory muscle force, which has been speculated to be due to a local fuel shortage in individual respiratory muscles (11). Although it is difficult to conceive how the slow twitch fiber of the respiratory muscles could become glycogen depleted, Vollestad et al. (44) demonstrated significant muscle fatigue of the quadriceps within the first few minutes of a low-intensity exercise. and Chevrolet et al. (11) suggested that respiratory muscle fatigue followed a pattern similar to that of leg muscle tiredness. Moreover, extravascular water accumulation would also have led to respiratory muscle fatigue by causing decreased pulmonary compliance $(7,35)$. Because we measured a $\mathrm{DL}_{\mathrm{CO}}$ decrease in post-C-R but not in post-R-R, we may also hypothesize that extravascular water accumulation occurred during C-R (8), which would enhance respiratory muscle fatigue.

Exercise-induced hypoxemia and pulmonary diffusing capacity. A significant and similar drop in $\mathrm{PaO}_{2}$ was observed during $\mathrm{C}-\mathrm{R}$ and $\mathrm{R}-\mathrm{R}$, with maximal drop values of $12-14 \mathrm{~mm} \mathrm{Hg}$. These decrements were smaller than those of $20-25 \mathrm{~mm} \mathrm{Hg}$ reported in other studies $(3,7,35)$ during incremental exercise, probably due to the relatively low exercise intensity. Pulmonary diffusing capacity was significantly decreased after C-R, but not after R-R. We did not measure postexercise HR. However, as HR was not different between C-R and R-R during and at the end of subsequent run, differences in cardiac output cannot explain this $\mathrm{DL}_{\mathrm{CO}}$ decrease (2). A decrease in $\mathrm{DL}_{\mathrm{CO}}$ has also been reported after longer exercise such as a marathon $(26,27)$ but has not been reported during exercise of such relatively short duration and moderate intensity as in the present study. The significant decrease in $\mathrm{DL}_{\mathrm{CO}}$ is surprising, given the correlation between exercise duration and the amplitude of the drop in $\mathrm{DL}_{\mathrm{CO}}$ reported by Manier et al. (26). Our value $(-7.7 \%)$, reported after a $50 \pm 2.40$ - $\mathrm{min}$ exercise, was greater than the $5 \%$ reduction reported by Caillaud et al. (8) after a $120 \pm 30$-min exercise, and it emphasizes the influence of the cycle-run trial. This decrease in $\mathrm{DL}_{\mathrm{CO}}$ noted after $\mathrm{C}-\mathrm{R}$ but not after $\mathrm{R}-\mathrm{R}$ suggests a greater pulmonary extravascular water accumulation $(8,26,27,35)$ during the cycle-run trial, which could be explained by the different fluid shifts that occur during cycling and running performance (45). Indeed, cycling results in a 
hemoconcentration and a rise in vascular resistance (40) that may induce an interstitial edema (47). In contrast, running generally induces an increase in plasma volume (21). Moreover, the significant increase in $\dot{\mathrm{V}}_{\mathrm{E}} / \mathrm{VO}_{2}$ and the inverse correlation between the rise in $\dot{V}_{\mathrm{E}}$ and the drop in $\mathrm{PaO}_{2}$ noted in $C-R$ versus $R-R$, concomitant with the $D L_{C O}$ decrease in C-R, suggest that EIH tended to increase more in $C-R$ versus $R-R$ but was stabilized by a greater ventilation. The decrease in $\mathrm{PaO}_{2}$ in $\mathrm{R}-\mathrm{R}$ that was not accompanied by a reduction in $\mathrm{DL}_{\mathrm{CO}}$ has been noted in a previous study (9), but it has not been adequately explained. A number of mechanisms have been proposed to explain this EIH, including a venoarterial shunt, a lower relative exercise hyperventilation and VA/Q inequalities, and diffusion limitation induced by either pulmonary edema or a reduction in red blood cell transit time through pulmonary capillaries (34). However, only a diffusion limitation induced by pulmonary edema has been demonstrated to be of major impact in EIH $(7,9,34)$. The exact mechanism of EIH remains nevertheless unclear (9). Other studies have demonstrated that neither arterial desaturation (37) nor oxyhemoglobin lesaturation (42) is related to lung transfer capacity as neasured by $\mathrm{DL}_{\mathrm{CO}}$ during dynamic exercise. This further supports the finding of a decrease in $\mathrm{PaO}_{2}$ without a concomitant $\mathrm{DL}_{\mathrm{CO}}$ decrease during exercise (9).

Cycle-run transition. There was an increase in the $\dot{V}_{\mathrm{E}}$ during the first $8 \mathrm{~min}$ of running in $C-R$ versus the first 8 min of running in $R-R$, concomitant with an increase in $f$ and $\dot{\mathrm{V}}_{\mathrm{E}} / \mathrm{VO}_{2}$ in the first 2 min of running in C-R compared with $R-R$. These two findings support the notion of the specificity of the cycle-run transition developed by Hue et al. (18), and they may be attributed to respiratory muscle fatigue and/or to pulmonary edema. Levine et al. (24) and Paintal (32) showed that pulmonary edema may result in hyperventilation by activation of the pulmonary $J$ receptors and that increases in both $\dot{V}_{E}$ and $f$ are indirect signs of respiratory muscle fatigue (5). Indeed, the greater $\dot{V}_{E}$ observed at the beginning of the run in $\mathrm{C}-\mathrm{R}$ could not have been related to

\section{REFERENCES}

1. American Thoracic Society. Single breath carbon monoxide diffusing capacity (transfer factor): recommendations for a standard technique. Am. Rev. Dis. 136:1299-1307, 1987.

2. ANDREW, G. M., and L. BaINES. Relationship of pulmonary diffusing capacity $\left(D_{L}\right)$ and cardiac output $\left(Q_{C}\right)$ in exercise. Eur. J. Appl. Physiol. 33:127-137, 1974.

3. Anselme, F., C. Caillaud, I. Couret, M. Rossi, and C. Prefaut. Histamine and exercise-induced hypoxemia in highly trained athletes. J. Appl. Physiol. 76:127-132, 1994.

4. Beaver, W. L., K. Wasserman, and B. J. Whipp. A new method for detecting anaerobic threshold by gas exchange. J. Appl. Physiol. $60: 2020-2027,1986$

5. BOUTELIER, U. Respiratory muscle fitness and exercise endurance in healthy human. Med. Sci. Sports Exerc. 30:1169-1172, 1998.

6. BuLow, L. Lipid mobilization and utilization: principles of exercise biochemistry. Med. Sport. Sci. 27:140-163, 1988.

7. Caillaud, C., F. Anselme, J. Mercier, and C. Prefaut. Pulmonary gas exchange and breathing pattern during and after exercise in highly trained athletes. Eur. J. Appl. Physiol. 67:431-437, 1993.

8. Caillaud, C., O. Serre-Cousine, F. Anselme, X. Capdevilla, and C. Prefaut. Computerized tomography and pulmonary diffusing a respiratory compensation for metabolic acidemia because of: 1) the lack of difference in ventilation in the first $30 \mathrm{~min}$ of cycling compared with the first $30 \mathrm{~min}$ of running, and 2) the lack of difference in respiratory exchange ratio (RER) during C-R compared with R-R, particularly during the first minute of running after cycling compared with running after running. The data from the present study suggest that cycling induces a decline in pulmonary function, which may be slowly reversed during the following run segment. Comparable results have been reported by Hill et al. (16), who assessed the effect of an endurance triathlon consisting of a $3.8-\mathrm{km}$ swim, a $180-\mathrm{km}$ cycle segment, and a $42-\mathrm{km}$ run on inspiratory and expiratory muscle strength. These investigators reported that the cycle segment induced a significant decrease in maximal inspiratory pressure caused by the crouched position of cycling, which increases abdominal impedance, thereby increasing diaphragmatic work. In their study, the maximal inspiratory pressure tended to increase again during the following running segment.

In summary, the cycle-run trial induced specific respiratory responses, including 1) a significant increase in the ventilatory responses in the first minute of running after cycling; 2) a significant increase in RV, FRC, and RV/TLC; and 3) a significant decrease in $\mathrm{DL}_{\mathrm{CO}}$. These changes may be due to respiratory muscle fatigue and/or an interstitial edema, both associated with cycling. However, both trials produced a similar magnitude of EIH, which suggests that mechanisms in addition to pulmonary diffusion capacity contribute to EIH. Lastly, the findings of the present study further develop the notion of the specificity of the cycle-run transition and reinforce the need for triathletes to practice multi-trial training to stimulate the physiological responses elicited by the cycle-run transition.

Address for correspondence: O. Hue, UFR-STAPS Antilles-Guyane, Campus de Fouillole, BP 592, 97159 Pointe à Pitre Cedex France. E-mail: Olivier.Hue@univ-ag.fr. capacity in highly trained athletes after performing a triathlon. J. Appl. Physiol. 79:1226-1232, 1995.

9. Caillaud, C., F. Anselme, and C. Prefaut. Effects of two successive maximal exercise tests on pulmonary gas exchange in athletes. Eur. J. Appl. Physiol. 74:141-147, 1996.

10. Cavanagh, P. R., and $K$. R. Williams. The effect of stride length variations on oxygen uptake during distance running. Med. Sci. Sports Exerc. 14:30-35, 1982.

11. Chevrolet, J. C., J. M. Tschopp, Y. Blanc, T. Rochat, and A. F. JUNOD. Alterations in inspiratory and leg muscle force and recovery pattern after a marathon. Med. Sci. Sports Exerc. 25:501-507, 1993.

12. Cordain, L., E. J. Rode, R. W. Gotshall, and A. Tucker. Residual lung volume and ventilatory muscle strength changes following maximal and submaximal exercise. Int. J. Sports Med. 15:158$161,1994$.

13. Davidson, R. J. L., J. D. Robertson, and R. J. Maughan. Hematological changes due to triathlon competition. Br. J. Sport Med. 20:159-151, 1986.

14. Guezennec, C. Y., J. M. Vallier, A. X. Bigard, and A. Durey Increase in energy cost of running at the end of a triathlon. Eur. J. Appl. Physiol. 73:440-445, 1996 
15. Hausswirth, C., A. X. Bigard, and C. Y. Guezennec. Relationship between running mechanics and energy cost of running at the end of a triathlon and a marathon. Int. J. Sports Med. 18:330-339, 1997.

16. HiLL, N. S., C. JACOBY, and H. W. FARBER. Effect of an endurance triathlon on pulmonary function. Med. Sci. Sports Exerc. 23: 1260-1264, 1991.

17. Hogberg, P. How do stride length and stride frequency influence the energy output during running? Arbeitphysiologie 14:437-441, 1952.

18. Hue, O., D. Le Gallais, D. Chollet, A. Boussana, and C. PreFAUT. The influence of prior cycling on biomechanical and cardiorespiratory response profiles during running in triathletes. Eur. J. Appl. Physiol. 77:98-105, 1997.

19. JAY, H. W., K. P. SCOTT, and M. K. STUART. Hb desaturation in highly trained athletes during heavy exercise. Med. Sci. Sports Exerc. 18:168-173, 1986.

20. Johnson, B. D., W. G. Reddan, D. F. Pegelow, K. C. Seow, and J. A DEMPSEY. Flow limitation and regulation of functional residual capacity during exercise in physically active aging population. Am. Rev. Respir. Dis. 143:960-967, 1991.

21. Kolka, M. A., L. A. Stephenson, and J. E. Wilkerson. Erythrocyte indices during a competitive marathon. J. Appl. Physiol. $52: 168-172,1982$.

22. Kreider, R. B., T. Boone, W. R. Thompson, S. Burkes, and C. W. Cortes. Cardiovascular and thermal responses of triathlon performance. Med. Sci. Sports Exerc. 20:385-390, 1988.

23. Kreider, R. B., D. E Cundiff, J. B. Hammet, C. W. Cortes, and $\mathrm{K}$. W. Whliam. Effects of cycling on running performance in triathletes. Ann. Sports Med. 3:220-225, 1988.

24. Levine, O. R., R. B. Mellins, and A. P. Fishman. Quantitative assessment of pulmonary edema. Circ. Res. 17:414-426, 1965.

25. MAdOR. J., and F. A. ACEVEDO. Effect of respiratory muscle fatigue on breathing pattern during incremental exercise. Am. Rev. Respir. Dis. 143:462-468, 1991

26. Manier, G., J. Moinard, P. Techoueyres, N. Varene, and H. Guenard. Pulmonary diffusion limitation after prolonged strenuous exercise. Respir. Physiol. 83:143-154, 1991.

27. Miles, D. S., C. E. Doeer, S. A. Schonfeld, D. E. Sinks, and R. W. GoTSHALL. Changes in pulmonary diffusing capacity and closing volume after running a marathon. Respir. Physiol. 52:349-359, 1983

28. Morgan, D. W., P. E. Martin, and G. S. Krahenbuhl. Factors affecting running economy. Sports Med. 7:310-330, 1989

29. Murray, J. F. The Normal Lung. Philadelphia: Saunders, 1986.

30. O'KroY, J. A., A. LoY, and J. R. COAST. Pulmonary function changes following exercise. Med. Sci. Sports Exerc. 24:13591364. 1992

31. O'Toole. M. L., and P. S. Dotglas. The ultraendurance triathlete: physiologic and medical considerations. Med. Sci. Sports Exerc. 21:198-199. 1989.
32. Paintal, A. S. Vagal sensory receptors and their reflex effects Physiol. Rev. 53:159-227, 1993.

33. Pivarnik, J. M., E. M. Leeds, and J. E. Wilkerson. Effect of endurance exercise on metabolic water production and plasma volume. J. Appl. Physiol. 56:613-618, 1984.

34. Powers, S, K., D. Martin, and S. DodD. Exercise-induced hypoxemia in elite endurance athletes: incidence, causes, and impact on VO $_{2 \max }$. Sports Med. 16:14-22, 1993.

35. Prefaut, C., F. Anselme, C. Caillaud, and J. Masse-Biron. Exercise-induced hypoxemia in older athletes. J. Appl. Physiol. 76 $120-126,1994$.

36. Quanjer, P. H., G. J. Tammeling, J. E. Cotes, O. F. Pedersen, R Peslin, and J. C. Yernault. Lung volumes and forced ventilatory flows. Eur. Respir. J. 16(Suppl.):5-40, 1993.

37. Rasmussen, J., B. Hanel, B. Diamant, and N. H. Secher. Muscle mass effect on arterial desaturation after maximal exercise. Med. Sci. Sports Exerc. 23:1349-1352, 1991.

38. Roalstad, M. S. Physiologic testing of the ultraendurance triathlete. Med. Sci. Sports Exerc, 21(Suppl.):S200-S204, 1989.

39. Schneider, D. A., K. A. Lacroix, G. R. Atkinson, P. J. Troped. and J. POLLACK. Ventilatory threshold and maximal oxygen uptake during cycling and running in triathletes. Med. Sci. Sports Exerc. 22:257-264, 1990.

40. Senay, L. C., JR ., G. Rogers, and P. Jooste. Changes in blood plasma during progressive treadmill and cycle exercise. J. Appl. Physiol. 49:59-65, 1980.

41. Sleivert, G. G., and H. A. Wenger. Physiological predictors of short-course triathlon performance. Med. Sci. Sports Exerc. 25 871-876, 1993.

42. Turcotte, R., L. Kiteala, J. E. Marcotte, and H. Perrault Exercise-induced oxyhemoglobin desaturation and pulmonary diffusing capacity during high-intensity exercise. Eur. J. Appl Physiol. 75:425:430, 1997

43. Van Rensburg, J. P., A. J. Kielbock, and A. Vanderlinde. Physiologic and biochemical changes during a triathlon competition. Int. J. Sports Med. 7:30-35, 1986.

44. Vollestad. N. K., O. M. Sejersted, R. Bahr, J. J. Woods, and B Bigland-Ritchie. Motor drive and metabolic responses durin repeated submaximal contractions in humans. J. Appl. Physiol 64:1421-1427, 1988

45. Wells, L. C., J. R. Stern., W. M. Kohrt, and K. D. Campbell. Fluid shifts with successive running and bicycling performance. Med. Sci. Sports Exerc. 19:137-142, 1987.

46. WILKInson, L. Systat: The System for Statistics. Evanston, IL: Systat, Inc.. 1990

47. Wood, S. C., M. P. Doyle, and O. Appenzeller. Effects of en durance training and long distance running on blood viscosity Med. Sci. Sports Exerc. 23:1265-1269, 1991. 
